\title{
Employees' Perception of Corporate Social Responsibility: Corporate Volunteer and Organizational Commitment
}

\author{
Chun-Chen Huang \\ Correspondence: Chun-Chen Huang, Assistant professor, Department of Business Administration, Asia University, \\ No.500, Liufeng Rd., Wufeng Dist., Taichung, Taiwan. E-mail: cchuang1127@gmail.com
}

Received: June 8, 2016

doi:10.5539/ibr.v9n9p142

\author{
Accepted: June 22, 2016 \\ Online Published: August 12, 2016 \\ URL: http://dx.doi.org/10.5539/ibr.v9n9p142
}

\begin{abstract}
Although there is a growing trend of corporate volunteer plans in Taiwan, there scanty studies on the antecedent and consequence variables that influence employees' participation in corporate volunteer. Most of existing studies concerning corporate social responsibility (CSR) explored the effects of CSR on corporate financial performance or consumer behavior, while paying little attention to the effects on the stakeholders and employees of enterprises. In practice, many enterprises often include corporate volunteer as an important part of their CSR policies. Past literature has seldom discussed the effects of the employees' perception of CSR on their participation in corporate volunteer. Most studies concerning corporate volunteer focus on volunteer participation motivation and intention of the volunteer services outside enterprises, while few focus on corporate employees' participation in corporate volunteer.

By convenience sampling, this study treated the 50 enterprises that received the Corporate Citizenship Award in 2012 as the targets. A total of 368 questionnaires were retrieved, including 195 paper-based questionnaires and 173 online questionnaires, among which there were 287 valid samples. The data were analyzed using SPSS18 to test the hypotheses. The findings of this study are as follows: (1) employees' perception of CSR has a significant positive effect on their intention to participate in corporate volunteer; (2) employees' perception of CSR has a significant positive effect on organizational commitment; (3) employees' intention of participating in corporate volunteer has a significant positive effect on organizational commitment.
\end{abstract}

Keywords: perception of corporate social responsibility, corporate volunteer, organization commitment

\section{Introduction}

Corporate volunteer has emerged in recent years as a new development trend of volunteer works, in addition to personal or group participation in volunteer. In Taiwan, many large enterprises encourage and sponsor their employees to participate in activities of public interest and volunteer. Through relevant corporate policies, enterprises motivate and even lead their employees to engage in volunteer works, thus, increasing and diversifying the opportunities and channels for employees to offer volunteer services. In the U.S., about 79-92\% of enterprises support corporate volunteer (Miller, 1997). A survey on the top 1,800 enterprises in the U.S. revealed that over half of those enterprises regard social services as one of their missions, and over one third regard corporate volunteer as one of the key corporate strategies (Wild, 1993). Despite the growing trend of corporate volunteer, few studies have investigated how to encourage employees' participation in corporate volunteer, as well as the antecedent and consequence variables that influence their participation.

The concept and practice of corporate social responsibility (CSR) has been a popular topic in corporate sustainable operation. Many enterprises have realized that a corporate image with social responsibility is a valuable and strategic asset to an enterprise. Most previous studies connected CSR with the benefits generated for stakeholders. Many studies have demonstrated that CSR performance can create many benefits, including stronger consumer satisfaction and better consumer remarks. Chang (2011) suggested that the internal stakeholders of enterprises have better access to the core of enterprises than external stakeholders, as well as many opportunities in policy-making of CSR. Many previous studies concerning CSR explored the effects of CSR on corporate financial performance or consumer behavior, while paying little attention to the effects on the stakeholders and employees of the enterprises (Larson, Flaherty, Brown, \& Wiener, 2008). Therefore, the effects of CSR performance on internal stakeholders, such as employees, have attracted increasing attention from researchers.

Few existing literature has discussed the effects of employees' perception of CSR on their participation in corporate volunteer. For instance (Kim, Lee M, Lee H \& Kim, 2010) divided corporate responsibility into CSR association and 
CSR participation, where the latter involves the plans concerning employee participation in corporate volunteer. They discussed the effects of employees' CSR association and CSR participation on their perceived external prestige, organizational identification, and organizational commitment. Nonetheless, it did not elaborate on the effects of employees' CSR perception of their CSR participation. As many enterprises in Taiwan include CSR plans as the key policy for the implementation of CSR, this study believes that it is important to discuss the effects of employees' CSR perception of their intention to participate in corporate volunteer. Additionally, many studies have demonstrated that the corporate volunteer plans can improve employees' attitude towards work, and help enterprises recruit or retain excellent employees (Backhaus, Stone \& Heiner, 2002; Wild, 1993). Hence, this study also aims to explore the effects of employees' CSR perceptions on their intention to participate in corporate volunteer, and whether such intention has effect on organizational commitment.

\section{Theoretical Foundations and Hypotheses}

\subsection{Corporate Social Responsibility (CSR)}

The concept of CSR, which originated in the 1950s, indicates that corporate performance is closely related to the public, and should be consistent with social values and expectations (Bowen, 1953). According to traditional views, an enterprise is shouldering its social responsibility if it maximizes its operational profits and provides inexpensive products. However, according to the socio-economic view, enterprises are like citizens, and their operations have effect on the economy, society, and the environment; hence, they should not focus solely on maximizing profits, but should shoulder more responsibility to reach a social balance (Davis, 1973; Friedman, 1970). For that reason, CSR is also called corporate citizenship, which covers a variety of issues, such as corporate moral, corporate governance, and green marketing. (Ferrell, Gonzalez-Padron, Hult \& Maignan, 2010) argued that, enterprises must be responsible for internal and external stakeholders: where internal stakeholders include shareholders, the board of directors, operational teams, and employees; while external stakeholders include consumers, suppliers, access, partners, competitors, local communities, and interest groups.

Carroll (1979) defined CSR as the social expectations of an organization during a certain period, including economic responsibility, legal responsibility, ethical responsibility, and spontaneous (charitable) responsibility. Economic responsibility means that enterprises effectively utilize their resources, and offer products or services at a reasonable price. Maintaining fair and stable competition in the industry and satisfying the interests and demands of stakeholders is the fundamental responsibility of enterprises. Legal responsibility requires enterprises to obey rules and regulations, and is the minimum social requirement of corporate responsibility. Legal regulations are incorporated into operational strategies and governance, and are related to various duties, such as manufacturing, consumption, laborer safety, and environmental protection, in order to protect stakeholders from damages. Ethical responsibility refers to the core values and principles of enterprises, which must be consistent with social ethical norms, social expectations, and prohibitions, in order to safeguard the rights and interests of stakeholders and public interest. Spontaneous responsibility means that enterprises transcend economic, legal, and ethical norms, take initiative to reward society, improve overall life, support national policies, and create a harmonious society.

\subsection{Corporate Volunteer}

Cihlar (2004) suggested that corporate volunteer is a planned managerial activity, where enterprises support and motivate employees to offer volunteer services with various resources, such as money, human resources, marketing, and public relations. Corporate volunteer can be carried out in many forms, such as offering paid holidays for volunteer services, so that employees can work in teams to assist social groups or participate in activities (Solomon, Ragland, Wilson \& Plost, 1991). The common volunteer targets include education, health and social relief, environment, and services for adolescents and children (Solomon, Ragland, Wilson \& Plost, 1991). Corporate volunteer can benefit many social groups, and many enterprises believe that it can contribute to their enterprises (Wild, 1993). Steel (1995) pointed out that corporate volunteer could lead to win-win outcomes among enterprises, employees, and social groups. From the perspective of the enterprise, corporate volunteer can bring enterprises various benefits that are beyond advertisement or marketing effects, such as improving the employees' skills related to work (Backhaus, Stone \& Heiner, 2002; Caudron, 1994), enhancing their written and spoken communication, time management, coordination, teamwork, and budget planning (Wild, 1993). Hence, corporate volunteer is a form of public relation activity that features low cost and great benefit, as well as the side product of professional training for employees, and has positive effects on teamwork spirit and internal cohesion (Boateng, 2003). From the perspective of employees, the group services of corporate volunteer can enhance their moral awareness (Lewin, 1991), confidence (Pancer, Baetz \& Rog, 2002), and willingness to share their values with organizations (Peterson, 2004b). For instance, employees can help disadvantageous groups to build websites, collect clothes and books for children in remote and impoverished areas, and plan tourism activities for community elderly. All of those experiences can enable participating employees to contribute their professionalism in 
the form of labor division, enrich personal professionalism and social experience, help them to establish confidence in work, sharpen their communication skills, and develop a more positive attitude towards life. Regarding the relationship between enterprises and society, corporate volunteer can be seen as a social marketing method of an enterprise. Corporate volunteer can improve the relationships among enterprises, social groups, and the government (Steel, 1995), and reduce public anger against or distrust in enterprises (Miller, 1997).

\subsection{Organizational Commitment}

Allen and Grisaffe (2001) pointed out that, most researchers agree that organizational commitment is the mental status of employees at work or within the organization, and indicates employees' intention to remain in the organization. Organizational commitment is defined as employees' emotional attachment to the organization, their interest in the organization, and their intention to be connected with the organization. Hunt, Wood and Chonko (1989) proposed that, employees who have strong commitment would accept the organization's objectives and values, and hope to remain as a part of the organization. Different researchers categorize organizational commitment in different ways, according to their research objectives. The categorization of organizational commitment is shown as follows: Porter, Steers, Mowday and Boulian (1974) classified organizational commitment into three types according to personal acceptance of the organization, personal willingness to remain in the organization, and the greater contribution to the organization: (1) value commitment: it means that employees believe in and accept the objectives and values of the organization; (2) retention commitment: it indicates that employees have a strong desire to remain a member of the organization; (3) effort commitment: it means that employees are willing to make more contributions to the organization. Stevens, Janice and Harrison (1978) divided organizational commitment into two types: (1) exchange commitment: the members of the organization would compare their endeavors to the reward they receive from the organization, in order to measure their degree of organizational commitment; (2) normative commitment: the members of the organization make contributions to the organization because they think they "should", and thus, hope that it follows the corporate norms. Meyer and Allen (1991) classified organizational commitment into three types: (1) affective commitment: it refers to personal emotional attachment to the organization; (2) normative commitment: the attachment to the organization is based on social norms, and employees believe that it is their responsibility to remain in the organization; (3) continuance commitment: the attachment to the organization is based on the cost employees must pay for leaving the organization, including pension, technical conversion, and the place of transformation, thus, they remain in the organization.

\section{Method}

\subsection{Research Structure and Hypothesis}

The public expectation on CSR has shifted beyond charitable activities of public interest to citizen-based participation of social inclusion. Therefore, many enterprises have made relevant policies to motivate or lead employees to participate in volunteer services, and strived to diversify employee's volunteer services through various methods. Although few studies have demonstrated the effects of employees' perceptions of CSR on their intention to participate in corporate volunteer, it is found that when employees are aware of enterprises' positive attitude towards CSR, they are more willing to practice the enterprises' missions and realize its objectives (Smidts, Pruyn, Th \& Riel, 2001; Bartels, Pruyn, Jong \& Joustra, 2007). Rupp, Ganapathi, Aguilera and Williams (2006) pointed out that employees' perception of CSR would influence their emotion, attitude, and behavior at work. Based on the above, this paper proposes the hypothesis as follows:

H1: The employees who have deeper perception of CSR have stronger intention to participate in corporate volunteer.

Kim et al. (2010) and Gilly and Wolfinbarger (1998) pointed out that the performance of enterprises in CSR affects employees' perceived external prestige. In other words, if employees learn from external stakeholders that their enterprises show CSR, they are more likely to be attracted to their enterprises' respectable characteristics and projected self-image (Lichtenstein, Drumwright \& Braig, 2004). Moreover, many studies have found that the degree to which employees accept their organizations is determined by the degree to which their enterprises are praised. Nevertheless, organizational identification can strengthen employees' attachment to, and concern for, their organizations, and then develop their organizational commitment. Dutton, Dukerich and Harquail (1994) suggested that if employees believe that their enterprises have social value, they would feel proud to be a part of the enterprises. Based on the above, this paper proposes hypothesis 2 :

H2: The employees who have deeper perception of CSR have stronger organizational commitment for their enterprises.

In most cases, organizational commitment is defined as employees' emotional attachment to an organization, their interest in the organization, and their intention of being connected with the organization. Hunt, Wood and Chonko (1989) suggested that, employees with strong commitment would accept the organization's objectives and values and hope to remain a part of the organization. Some literature has shown that, corporate volunteer can improve employees' attitude 
regarding work, organizational commitment, and job satisfaction (Stebbins, 1989), and enhance their loyalty to the enterprise (Backhaus, Stone \& Heiner, 2002; Carroll, 1990). Peterson (2004b) proposed that the organizational commitment of the employees who participate in volunteer is stronger than that of those who do not. Corporate volunteer can enhance employees' moral excellence and confidence, increase their intention of sharing value with the organization, satisfy their higher demands (Schwochau, Delaney, Jarley \& Fiorito, 1997), and reinforce their acceptance of the organization. In addition, many studies have found that organizational identification would influence employees' psychological attachment to the organization, in turn, the organization generates commitment. Based on the above, this paper proposes hypothesis 3 :

H3: The employees who have stronger intention to participate in corporate volunteer have stronger organizational commitment for enterprises.

Thus, based on the literature on the relationship among variables, this study developed the research framework in Figure 1.

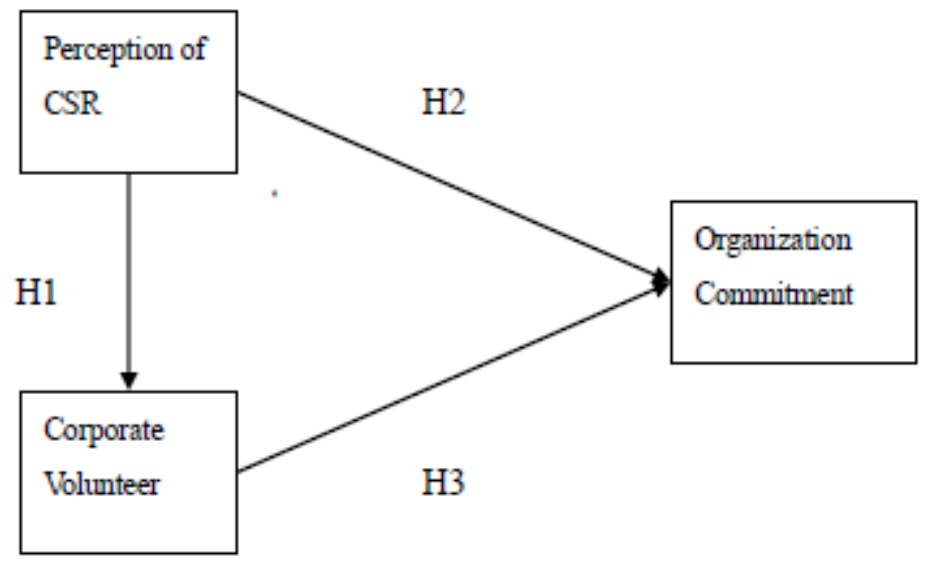

Figure 1. Research Framework

\subsection{Measurement of the Constructs}

The three variables of this research are measured using a five-point Likert scale, ranging from 1 (strongly disagree) to 5 (strongly agree). Regarding corporate responsibility perception, this study referred to Maignan and Ferrell (2000) and Carroll (1979) to develop 18 items for CSR classification. The scale features high reliability and validity. Peterson (2004a) also employed this scale to measure employees' CSR perception.

Wild (1993) mentioned that participation in corporate volunteer means that enterprises motivate employees to mobilize or participate in nonprofit organizations, and that employees offer their time and skills to participate in volunteer. Maclagan (1999) suggested that participation in corporate volunteer involves giving suggestions regarding the CSR policies. Therefore, participation in corporate volunteer can be regarded as participatory behavior (Kim et al., 2010). The measurement of the participation in corporate volunteer is based on the concept of Kim et al. (2010), the scale includes the following two items, with reliability of 0.78 .

The organizational commitment scale is based on the three component model, as proposed by (Meyer \& Allen, 1991), including affective commitment, continued commitment, and normative commitment. The organizational commitment scale, as developed by Meyer, Allen, and Smith (1993), was also adopted, and its overall reliability is 0.89. Many empirical studies have demonstrated that the organizational commitment scale, which is comprised of 14 items to measure employees' acceptance of their current job, has high reliability and validity.

\subsection{Sample}

By convenience sampling, this study, this study treated 50 enterprises that won the Corporate Citizenship Award in 2012 as the targets. A total of 368 questionnaires were retrieved, including 195 paper-based questionnaires and 173 online questionnaires. After eliminating 81 invalid samples, there were 287 valid samples, with a valid return rate of $77.99 \%$.

Among the samples, there are $47.0 \%$ male respondents and $53.0 \%$ female respondents, mostly have university education (48.4\%), followed by master's degree (20.9\%), under the age of 40 years old $(58.9 \%)$, have 1 to 5 years of volunteer experience (62.4\%), and spend 10 hours or less on corporate volunteer within the past 3 months (79.4\%).

\subsection{Reliability of Research Constructs}

In this study, principle components analysis was adopted to extract the factors, and Varimax was used for the orthogonal rotation to extract the factors with eigenvalues higher than 1 and absolute value of factor loading higher than 0.6. After 
factor analysis, three factors were extracted from the corporate responsibility scale, namely (1) legal and moral responsibility, (2) charitable responsibility, and (3) economic responsibility. The cumulative percentage of variance was $69.295 \%$, and Cronbach's alpha of the factors remained between 0.708 and 0.835 . There were 5 items regarding the intention to participate in corporate volunteer. One factor was extracted, with a variant explanatory percentage of $74.080 \%$ and Cronbach's alpha of 0.912 . Three factors were extracted from the organizational commitment scale, namely, (1) affective commitment; (2) continued commitment; (3) normative commitment. The cumulative percentage variance was $77.5444 \%$, while Cronbach's alpha of the factors remained between 0.486 and 0.927 .

Table 1. Reliability, Mean and Standard Deviation of Constructs

\begin{tabular}{|c|c|c|c|c|}
\hline Variable & Construct & $\begin{array}{l}\text { Cronbach's } \\
\text { alpha }\end{array}$ & Mean & $\begin{array}{l}\text { Standard } \\
\text { deviation }\end{array}$ \\
\hline \multirow{4}{*}{ Perception of CSR } & & & 4.154 & 0.513 \\
\hline & $\begin{array}{l}\text { Legal and moral } \\
\text { responsibility }\end{array}$ & 0.835 & 4.131 & 0.639 \\
\hline & $\begin{array}{l}\text { Philanthropic } \\
\text { responsibility }\end{array}$ & 0.811 & 4.071 & 0.699 \\
\hline & Economic responsibility & 0.708 & 4.261 & 0.685 \\
\hline $\begin{array}{l}\text { Corporate } \\
\text { volunteer }\end{array}$ & $\begin{array}{l}\text { Intention to participate } \\
\text { in corporate volunteer } \\
\text { work }\end{array}$ & 0.912 & 3.816 & 0.727 \\
\hline \multirow{4}{*}{$\begin{array}{l}\text { Organizational } \\
\text { commitment }\end{array}$} & & & 3.380 & 0.598 \\
\hline & Affective commitment & 0.927 & 3.739 & 1.027 \\
\hline & Continued commitment & 0.486 & 3.700 & 0.999 \\
\hline & Normative commitment & 0.527 & 2.523 & 0.825 \\
\hline
\end{tabular}

\section{Data Analysis and Results}

Table 1 shows the means and standard deviations of the dimensions of this study. The mean of CSR perception is 4.1535; the mean of enterprises' CSR implementation and economic responsibility, as perceived by employees, rank the highest $(M=4.2605)$, followed by the mean of legal and moral responsibility $(M=4.1308)$ and the mean of charitable responsibility $(\mathrm{M}=4.0711)$. The mean of the intention to participate in corporate volunteer is 3.8159 . The mean of organizational commitment is 3.3803 . The mean of affective commitment ranks the highest $(\mathrm{M}=3.7387)$, followed by the mean of continued commitment $(\mathrm{M}=3.7003)$, and the mean of normative commitment $(\mathrm{M}=2.5226)$.

According to regression analysis, as shown in Table 2, Regression Model 1 shows that, employees' CSR perception has a significant positive effect on their intention to participate in corporate volunteer. In other words, if employees are aware that enterprises emphasize social responsibility, they would be willing to participate in corporate volunteer. Therefore, H1 is valid. Additionally, Regression Model 2 shows that, employees' CSR perception has a significant positive effect on organizational commitment. In other words, if an enterprise has a higher level of CSR implementation, its employees would have stronger organizational commitment. Therefore, $\mathrm{H} 3$ is valid. Regression Model 2 also shows that the strategy of motivating participation in corporate volunteer has a significant positive effect on employees' intention to participate in corporate volunteer. In other words, when an enterprise actively makes strategies for motivating employees to participate in corporate volunteer, its employees would have stronger intention to participate in corporate volunteer. Hence, $\mathrm{H} 2$ is valid. According to Regression Model 3, employees' intention to participate in corporate volunteer has a significant positive effect on organizational commitment. In other words, employees' participation in corporate volunteer can enhance their organizational commitment to their enterprise. Therefore, H3 is valid. Moreover, this study conducted further discussion on the effects of the three dimensions of employees' CSR perceptions regarding their intention to participate in corporate volunteer. Multiple regression analysis, as shown in Table 3, finds that the implementation level $\left(\beta=0.252^{* * *}\right)$ of enterprises' charitable responsibility has the greatest effect on their intention to participate in corporate volunteer, followed by legal and moral responsibilities $\left(\beta=0.230^{* * *}\right)$.

Table 2. Simple Regression Analyses

\begin{tabular}{|c|c|c|c|c|c|}
\hline & Constructs & $\begin{array}{l}\text { Standardized } \\
\text { beta }\end{array}$ & $\mathrm{R}^{2}$ & $\begin{array}{l}\text { Adjusted } \\
\mathrm{R}^{2}\end{array}$ & F-value \\
\hline Model 1 & $\begin{array}{l}\text { perception of } \\
\text { volunteer }\end{array}$ CSR $\rightarrow \quad$ Corporate & $0.553 * * *$ & 0.306 & 0.303 & 124.719 \\
\hline Model 2 & $\begin{array}{l}\text { perception of CSR } \rightarrow \text { Organizational } \\
\text { commitment }\end{array}$ & $0.402 * * *$ & 0.162 & 0.159 & 54.540 \\
\hline Model 3 & $\begin{array}{l}\text { Corporate volunteer } \rightarrow \text { Organizational } \\
\text { commitment }\end{array}$ & $0.311 * * *$ & 0.097 & 0.094 & 30.363 \\
\hline
\end{tabular}


Table 3. Multiple Regression Analysis

\begin{tabular}{|c|c|c|c|c|c|c|}
\hline \multirow{4}{*}{ Model 4} & $\begin{array}{l}\text { Dependent } \\
\text { Variables }\end{array}$ & $\begin{array}{l}\text { Independent } \\
\text { Variables }\end{array}$ & Standardized beta & $\mathrm{R}^{2}$ & Adjusted $\mathrm{R}^{2}$ & F-value \\
\hline & \multirow[t]{3}{*}{$\begin{array}{l}\text { Corporate } \\
\text { volunteer }\end{array}$} & $\begin{array}{l}\text { legal and ethical } \\
\text { responsibility }\end{array}$ & $0.235 * * *$ & \multirow[t]{3}{*}{0.366} & \multirow[t]{3}{*}{0.359} & \multirow[t]{3}{*}{54.407} \\
\hline & & $\begin{array}{l}\text { philanthropic } \\
\text { responsibility }\end{array}$ & $0.406 * * *$ & & & \\
\hline & & $\begin{array}{l}\text { economic } \\
\text { responsibility }\end{array}$ & 0.008 & & & \\
\hline
\end{tabular}

\section{Discussion of Finding}

This study explored the effect of employees' CSR, as brought by the degree to which enterprises perform corporate morality, on employees' intention to participate in corporate volunteer and their organizational commitment. According to the means of the three factors regarding employees' CSR perceptions, employees believe that economic responsibility ranks highest in corporate implementation, followed by legal and moral responsibility, and then charitable responsibility. This indicates that, the CSR that Taiwanese enterprises attach the greatest importance to is reducing cost and pursuing maximum profits, which is followed by relevant legal and moral responsibility (such as offering complete behavioral norms and providing a fair and trustful environment for employees), and by relevant charitable activities. According to the three dimensions of employees' CSR perception in Regression Model 4, charitable responsibility is the most effective in motivating employees to participate in corporate volunteer, followed by legal and moral responsibility, and economic responsibility. However, this study showed that charitable responsibility ranks the lowest among the three dimensions regarding employees' CSR perception $(\mathrm{M}=4.0711)$. Hence, this study argued that enterprises should give priority to non-economic CSR aspects in performing activities of CSR. This result also fills the gap left by previous literature, discussions regarding the antecedent variables that influence employees' intention to participate in corporate volunteer.

This study found that CSR perception has a significant positive effect on employees' intention to participate in corporate volunteer and organizational commitment. In the implementation of CSR, most enterprises would consider external interested parties. Therefore, employees would develop perception according to the remarks of external interested parties on the CRS of enterprises. More importantly, employees' subjective perception of and remarks on the CRS of enterprises also play a key role. If employees know that the enterprises they work for have social responsibility, they would be more willing to participate in corporate volunteer, and thus, enhance their organizational commitment. Moreover, if employees have stronger intention to participate in corporate volunteer, they can satisfy higher-level psychological demands and achieve profound self-exploration by participating in corporate volunteer and would even have stronger organizational commitment. This result is consistent with (Schwochau, Delaney, Jarley \& Fiorito, 1997) and (Smidts, Pruyn, Th \& Riel, 2001), and demonstrates that there is a positive relationship between participation in corporate volunteer and organizational identification.

This study found that the effects of employees' CSR perception on organizational commitment were stronger than employees' participation in corporate volunteer. If enterprises expect stronger organizational commitment from employees, they should pay more attention to the communication related to social responsibility in the companies and show employees that they are striving to take social responsibility.

\section{Conclusions and Implications}

According to the results of this study, enhancing employees' CSR perception and corporate volunteer responsibility can strengthen their organizational commitment. Hence, in the practice and popularization of the principles of social responsibility, enterprises should not only provide information for such external interested parties as consumers, investors, suppliers, the public and communities but also offer positive CSR-related information to employees in an effective way. Only by doing this can they create more benefits in the organization and further improve organizational performance.

In addition, this study also found that corporate volunteer is an effective policy to link external stakeholders with internal stakeholders (employees) in terms of CSR. If enterprises perform well in this aspect, they would win positive remarks from external stakeholders and influence internal stakeholders (employees). As a result, employees are more likely to be attracted by enterprises' respectful characteristics, perform as expected by the enterprises, are more willing to participate in corporate volunteer, have higher employees' organizational commitment, thus creating win-win outcome among enterprises, employees, and nonprofit organizations.

As for the research limitation, as the questionnaires of this study include both online and paper-based questionnaires, they were not personally distributed; instead, distribution was assisted by relevant corporate volunteer work departments. Moreover, the characteristics of the demographic statistical variables regarding the respondents were limited due to the varied characteristics of the enterprises. Thirdly, all variables in this study were self-evaluated by the 
respondents, thus, there may be common method variance, which affect the descriptions of the actual situations. It is suggested that future studies should adopt the information source separation method to divide variable information areas into different collection sources and pair them to form a complete questionnaire according to research focuses after the retrieval. An alternative is to use relevant information in the organization, including the records about employees' participation in volunteer, so as to avoid common method variance.

\section{Acknowledgements}

The author would like to acknowledge the financial support (NSC 102-2410-H-468-028-) from the Ministry of Science and Technology of Taiwan.

\section{References}

Allen, N. J., \& Grisaffe, D. B. (2001). Employee Commitment to the Organization and Customer Reactions Mapping the Linkages. Human Resource management Review, 11(3), 209-236. http://dx.doi.org/10.1016/S1053-4822(00)00049-8

Backhaus, K. B., Stone, B. A., \& Heiner, K. (2002). Exploring the relationship between corporate social performance and employer attractiveness. Business \& Society, 41, 292-318. http://dx.doi.org/10.1177/0007650302041003003

Bartels, J., Pruyn, A., Jong, M., \& Joustra, I. (2007). Multiple organizational identification levels and the impact of perceived external prestige and communication climate. Journal of Organizational Behavior, 28(2), 173-190. http://dx.doi.org/10.1002/job.420

Boateng, J. V. (2003). Enhancing business-community relations: corporate responsibility movement case study. www.new-academy.ac.uk

Bowen, H. R. (1953). Social responsibility of the businessman, New York: Harper \& Row.

Carroll, A. B. (1979). A three-dimensional conceptual model of corporate performance. Academy of Management Review, 4(4), 497-505.

Carroll, P. B. (1990). Chivas regal report on working Americans: emerging values for the 1990s. Wall Street Journal (August 10), B6.

Caudron, S. (1994). Volunteer efforts offer low-cost training options. Personnel Journal, 73, 38-44.

Chang, Y. C. (2011). The influence of perceived corporate social responsibility and voluntary participation on employees' organizational citizenship behavior (Unpublished master dissertation). National Chengchi University, Taiwan.

Cihlar, C. (2004). The State of Knowledge Surrounding Employee Volunteer in the Unite State, Washington, D. C., Points of Light Foundation.

Davis, K. (1973). The case for and against business assumption of social responsibility. Academy of Management Journal, 16, 312. http://dx.doi.org/10.2307/255331

Dutton, J. E., Dukerich, J. M., \& Harquail, C. V. (1994). Organizational images and member identification. Administrative science Quarterly, 39(2), 239-263. http://dx.doi.org/10.2307/2393235

Ferrell, O., Gonzalez-Padron, T. L., Hult, G. T. M., \& Maignan, I. (2010). From market orientation to stakeholder orientation. Journal of Public Policy \& Marketing, 29(1), 93-96. http://dx.doi.org/10.1509/jppm.29.1.93

Friedman, M. (1970). The social responsibility of business is to increase its profits, New York Times Magazine, 13, 122-126.

Gilly, M. C., \& Wolfinbarger, M. (1998). Advertising's internal audience. Journal of Marketing, 62(1), 69-88. http://dx.doi.org/10.2307/1251804

Guzley, R. M. (1992). Organizational climate and communication climate: predictors of commitment to the organization. Management Communication Quarterly, 5(4), 379-402. http://dx.doi.org/10.1177/0893318992005004001

Hunt, S. D., Wood, V. R., \& Chonko, L. B. (1989). Corporate ethical values and organizational commitment in marketing. Journal of Marketing, 53, 79-90. http://dx.doi.org/10.2307/1251344

Jaros, S. J. (1997). An assessment of Meyer and Allen's (1991) three-component model of organizational commitment and turnover intentions. Journal of Vocational Behavior, 51, 319-337. http://dx.doi.org/10.1006/jvbe.1995.1553

Kim, H. R., Lee, M., Lee, H. T., \& Kim, N. M. (2010). Corporate social responsibility and employee-company identification. Journal of Business Ethics, 95(4), 557-569. http://dx.doi.org/10.1007/s10551-010-0440-2

Larson, B. V., Flaherty, K. E., Zablah, A. R., Brown, T. J., \& Wiener, J. L. (2008). Linking cause-related marketing to sales force responses and performance in a direct selling context. Journal of Academic Marketing Science, 36, 271-277. http://dx.doi.org/10.1007/s11747-007-0056-y 
Lewin, D. (1991). Community Involvement, Employee Morale, and Business Performance, IBM Worldwide Social Responsibility Conference.

Lichtenstein, D. R., Drumwright, M. E., \& Braig, B. M. (2004). The effect of corporate social responsibility on customer donations to corporate-supported nonprofits. Journal of Marketing, 68(4), 16-32. http://dx.doi.org/10.1509/jmkg.68.4.16.42726

Maclagan, P. (1999). Corporate social responsibility as a participative process, Business Ethics: A European Review, 8(1), 43-49.

Maignan, I., \& Ferrell, O. C. (2000). Measuring Corporate Citizenship in Two Countries: The Case of the United States and France. Journal of Business Ethics, 23(3), 283-297. http://dx.doi.org/10.1023/A:1006262325211

Meyer, J. P., \& Allen, N. J. (1991). A three-component conceptualization of organizational commitment. Human Resource Management Review, 1, 61-89. http://dx.doi.org/10.1016/1053-4822(91)90011-Z

Meyer, J. P., Allen, N. J., \& Smith, C. A. (1993). Commitment to Organizations and Occupations: Extension and Test of a Three-component Conceptualization. Journal of Applied Psychology, 78, 538-551. http://dx.doi.org/10.1037/0021-9010.78.4.538

Miller, W. H. (1997). Volunteerism: a new strategic tool, Industry Week, 1, 13-16.

Pancer, S. M., Baetz, M. C., \& Rog, E. J. ( 2002). Developing an Effective Corporate Volunteer Program: Lessons from the Ford Motor Company of Canada Experience (Canadian Center for Philanthropy, Toronto, ON).

Peterson, D. K. (2004a). The relationship between perceptions of corporate citizenship and organizational commitment. Business \& Society, 43(3), 296-319. http://dx.doi.org/10.1177/0007650304268065

Peterson, D. K. (2004b). Benefits of participation in corporate volunteer programs: employees perceptions. Personnel Review, 33(6), 615-627. http://dx.doi.org/10.1108/00483480410561510

Porter, L. W., Steers, R. M., Mowday, R. T., \& Boulian, P. V. (1974). Organizational commitment, job satisfaction and turnover among psychiatric technicians. Journal of Applied Psychology, 59(5), 603-609. http://dx.doi.org/10.1037/h0037335

Rupp, D. E., Ganapathi, J., Aguilera, R. V., \& Williams, C. A. (2006). Employee reactions to corporate social responsibility: An organizational justice framework. Journal of Organizational Behavior, 27(4), 537-543. http://dx.doi.org/10.1002/job.380

Schwochau, S., Delaney, J., Jarley, P., \& Fiorito, J. (1997). Employee participation and assessments of support for organizational policy changes. Journal of Labor Research, 18(3), 379-401. http://dx.doi.org/10.1007/s12122-997-1046-z

Smidts, A., Pruyn, A. D., Th, H., \& Riel, C. B. M. (2001). The impact of employee communication and perceived external prestige on organizational identification. Academy of Management Journal, 49(5), 1051-1062. http://dx.doi.org/10.2307/3069448

Solomon, S. W., Ragland, B. O., Wilson, R. E., \& Plost, M. (1991). Encouraging company employees to volunteer. In Shannon J. P. (ed.). The corporate contributions handbook. (Jossey-Bass Publishers, San Francisco, CA).

Stebbins, S. J. (1989). The influence of community service volunteer work on perceptions of job satisfaction and organizational commitment among Oregon employees of pacific northwest bell, unpublished doctoral dissertation, Oregon state university, Corvallis, OR.

Steel, K. (1995). Managing corporate and employee volunteer programs, In T. D. Connors (ed.). The volunteer management handbook (Wiley \& Sons, New York, NY).

Stevens, J. M., Janice, B. M., \& Harrison, T. M. (1978). Assessing personal role, and organizational predictors of managerial commitment. Academy of Management Journal, 21, 380-396. http://dx.doi.org/10.2307/255721

Wild, C. (1993). Corporate volunteer programs: benefits to business. The Conference Board Report \#1029, New York, NY.

\section{Copyrights}

Copyright for this article is retained by the author(s), with first publication rights granted to the journal.

This is an open-access article distributed under the terms and conditions of the Creative Commons Attribution license (http://creativecommons.org/licenses/by/4.0/). 